\title{
Carp land: Economics of fish farms and the impact of region-marketing in the Aischgrund (DEU) and Barycz Valley (POL)
}

\author{
Lasner Tobias ${ }^{1,}{ }^{*}$, Mytlewski Adam ${ }^{2}$, Nourry Myriam ${ }^{3}$, Rakowski Marcin ${ }^{2}$, Oberle Martin 4
}

1 Thunen Inst Fisheries Ecol, Herwigstr 31, D-27572 Bremerhaven, Germany.

2 Natl Marine Fisheries Res Inst, UI Kollataja 1, PL-81332 Gdynia, Poland.

3 UMR AMURE Univ Bretagne Occidentale, 12 Rue Kergoal, F-29238 Brest 3, France.

${ }^{4}$ LfL Bavarian Inst Fisheries, Greiendorfer Weg 8, D-91315 Hochstadt, Germany.

* Corresponding author : Tobias Lasner, email address : tobias.lasner@thuenen.de

\begin{abstract}
:
The carp farmers of today face many challenges, with changing consumer habits, drought, losses of fish to avian predators and diseases presenting some of the most widespread threats. Our study has selected two European carp-farming areas as case studies: the Aischgrund in Germany and the Barycz Valley in Poland, where local stakeholders have initiated region-marketing concepts. The carp provides the core identity of these region-marketing. The region-marketing aims to boost touristic attractiveness of the regions and should indirectly support carp farmers in the strained economic situation for carp aquaculture. Notwithstanding, it is unknown, how the region-marketing effects carp farms' economics. Stakeholders were interviewed to explore the establishment and the essence of these region-marketing concepts. Focus groups of carp farmers have informed our sample of representative farms. The representative farm models enabled to compare the costs and profitability of different carp enterprises. Further, the farm models helped to explore the potential impacts and efficacy of region-marketing initiatives introduced in recent years. Our results show that the single grow-out and traditional sale of conventional fresh carp is scarcely profitable. Farmers in both regions struggle with limited options for adaptation or diversification. The difficulties are most pronounced for small-scale peasant carp farms. We consider the potential of labelling as part of region-marketing and future transfer payments that honor the contribution of carp farming to ecosystem services and cultural value (region's identity). In particular for larger-scaled carp farms, region-marketing seems to be a good means of enhancing direct marketing opportunities and generating new income sources via diversification.
\end{abstract}




\section{Highlights}

- The study examines the profitability of carp farms in Polish Barycz Valley and German Aischgrund. Representative farm models show that the economic situation of carp farmers is harsh today, in particular for smallholders. Fisheries Local Action Groups promote the local economy with the carp as core identity. It is discussed what positive impact an increased tourism has towards carp farms.

Keywords : Benchmarking, Focus group, Profitability, Protected Geographic Indication (PGI), Stakeholder interviews 
The Common carp, Cyprinus carpio is the longest farmed species in European freshwater

Figure 1: Carp production by main producers in Europe 2007 - $2016[12,13,14]$

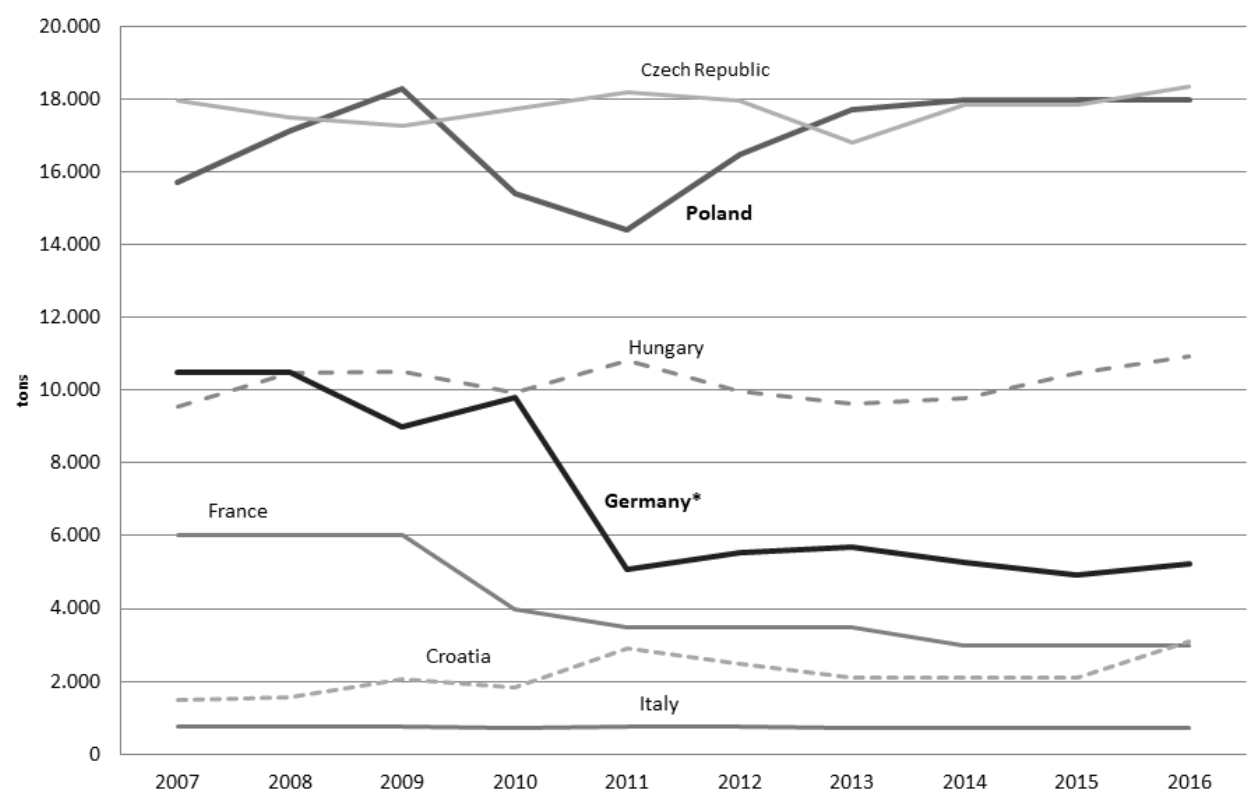
aquaculture [1,2], with a history dating back almost 1,000 years in Germany and Poland. The Frankish Carolingian dynasty provided systematic support for the construction and maintenance of carp ponds in the medieval era [3,4]. The Cistercian monastic order played a central role in the domestication of carp in Central and Eastern Europe. The monks reared carp as food for periods of Christian abstinence [4,5]. Their extensive polycultural techniques are still used by many present day carp farmers and are seen as a low input aquaculture [6], providing both cultural and ecosystem services [7,8]. Earthen ponds share a common construction method and tend to differ only in scale, stocking density and water source, with the latter most commonly derived from either precipitation or surface water (e.g. a river). Therefore, annual carp production depends heavily on climate. Ponds filled exclusively by precipitation, are known as "Himmelsteiche" or 'sky ponds' [9].

Today, global carp aquaculture increases and is led by China with a production of more than 3 million mt of common carp in 2017 [10]. In contrast, the European carp production oscillates around $78,000 \mathrm{mt}^{1}$ per year $[11,12]$. Small-scale peasant farms are the dominant form of carp production in Western Europe, while medium to large-scale farms are more typical in Middle and Eastern Europe. The origins of the disparity lie in a mixture of geographical preconditions (water supply, soil quality and landscape), historical background (smallholder agriculture versus large landowner squirearchy), and from more recent political and economic drivers (such as those between market and planned economies). Within the EU, Poland and the Czech Republic are the largest producers of carp, contributing half of all production, followed by Hungary and Germany (Figure 1).

\footnotetext{
*The apparent decline in German carp production is a result of changing survey methods, in which official statistics now only count fish sold for human consumption and not those sold for re-stocking purposes. There is an ongoing discussion in Germany about the validity of current statistics [15], with values for cultured area and the aquacultural production appearing to be underestimated in several regions [16,17].
}

With the exception of the Czech Republic, most markets for common carp within the EU are domestic ones. Poland is the main European market for live carp, with a stable consumption of more than 21,000 mt. Demand has a strong seasonal peak around Christmas, in line with catholic culture. The domestic annual carp production is around $18,000 \mathrm{mt}$ and the total area of ponds amounts to 82,371 hectare (ha) $[12,18,19]$. Although there is a duty of registration, figures for the exact number of

\footnotetext{
1 Unless otherwise stated, all weights given refer to live weight of carp. Tons refer to metric tons (mt).
} 
carp farms vary. According to official statistics, the total was only 400 in 2013 [18], while a survey undertaken by Lirski \& Myszkowski [19] included interviews with 733 Polish carp farmers, producing fry and fish for consumption and (re-)stocking. Germany is the most important European importer of carp, with a total market of around 7,600 $\mathrm{mt}$ in 2015, of which more than 2,600 $\mathrm{mt}$ were imported [13]. According to official statistics, German carp production amounted to around 5,000 mt [14]. The majority of carp farms in Germany are small family businesses producing less than $1 \mathrm{mt}$ of carp per year. Although there are almost 3,900 of these small-scale farms, they contribute only 10 percent to national carp production [20]. Carp production in Germany is dominated by fewer than 200 large farms, the majority of farms are characterized by peasant production $(\leq 5 \mathrm{mt})$. Most carp farms and the majority of production (86 percent) are located in Bavaria, Saxony ${ }^{2}$ and Brandenburg [14]. Although a range of processed carp products are available, the traditional market for fresh slaughtered or live carp to be prepared at home is still significant.

In some regions of Europe, such as the German Aischgrund and Polish Barycz Valley (Figure 2), carp farming continues to characterize both local landscape and culture. The Aischgrund lies within Bavaria and is thus also part of Middle Franconia. The landscape incorporates some 7,000 ponds with a total pond area of around 2,300 ha [9]. Most of them date back to the $16^{\text {th }}$ century, and most are rain fed 'sky ponds'. Almost 15 percent of ponds in the region are classified as nature reserves, as special protected area or as Natura 2000 sites. A total of 48 carp farms are located in the Lower Silesia Province $(8,493 \mathrm{ha})$. The river Barycz provides the main water supply. Simultaneously, its valley offers habitat for rare water birds. The Barycz Valley Landscape Park was created in 1996, so the region now comprises both Europe's largest carp breeding center and Poland's largest nature reserve. Carp production has continued in Barycz Valley for over 800 years.

Figure 2: Location of the two carp producing study regions of Aischgrund in Germany and Poland's Barycz Valley, with regional emblems (according to LAG Aischgrund, Karpfenland Travel, UNEP/GRID-Warszawa, Partnerstwo dla Doliny Baryczy, not drawn to scale)

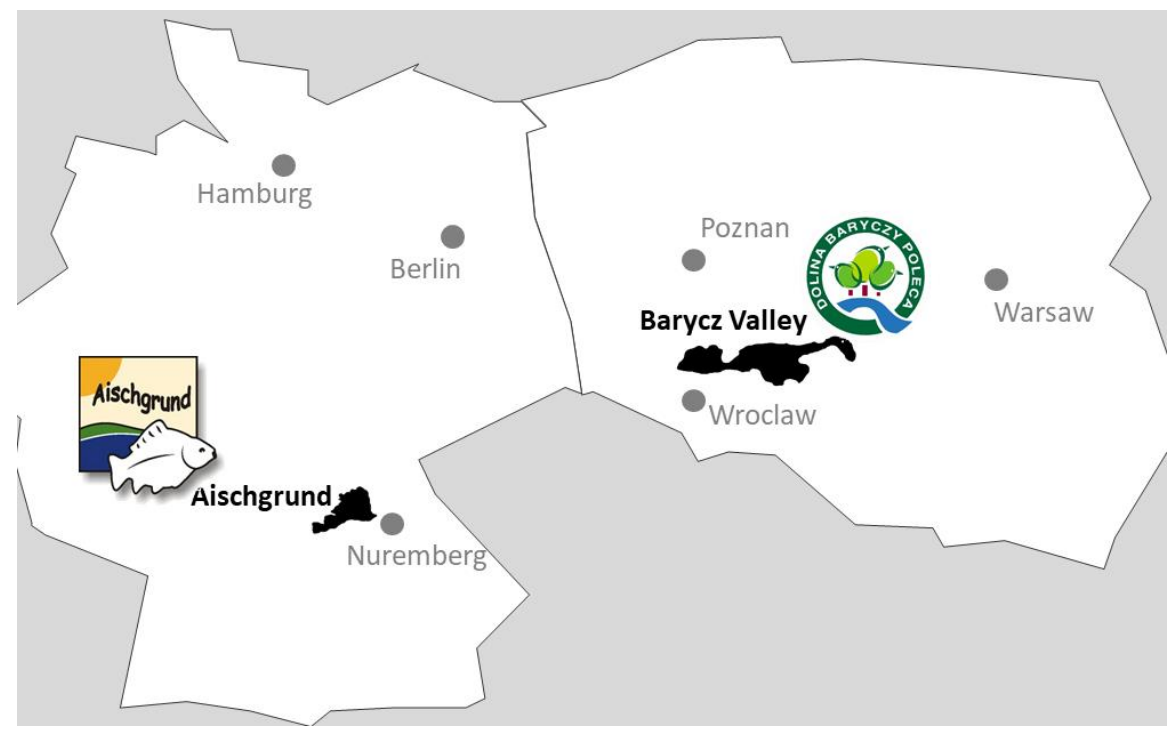

In the Aischgrund, a strong and stable local demand for carp is met mostly by the small peasant carp farms that characterize the region. In the Barycz Valley, 28 private producers and the publicly owned company Stawy Milickie dominate the carp production and provide the national Polish carp

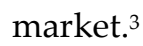

\footnotetext{
${ }^{2}$ In contrast to the Bavarian Aischgrund, in Saxony, there are fewer farms (152), but larger-scaled and typically managed on a full-time professional basis $[14,4]$.

${ }^{3}$ Stawy Milickie is not an object of our study, because it does not fully take part in the free market economies as public institution.
} 
Since the millennium, a marketing concept has been launched as framework for diverse measures in each of the both regions. The concepts aim to increase the regions' profile and attractiveness to visitors. Although the concept of region is gaining public traction, there is no common scientific definition of what the term 'region' might mean [21]. In general geographic parlance, a region is a coherent, medium-sized surface with functional or structural borders [22], enclosing an area in which a certain homogeneity exists. According to the economists Kotler, Haider and Rein [23,24], region-marketing is a coherent programme of communication, promotion, advertisement, and cooperation by collaborating private and public partners, aiming to attract investment from third parties within a defined region. The German geoscientist Tamara Linsteadt further notes: "Region-marketing is a process and market-orientated concept, which is adjusted to individual demands to prepare, initiate and influence the development of a region. Region-marketing serves as communication and coordination platform. Region-marketing consolidates regional forces and competences and activates networks to gain a competitive advantage over other regions" [22] (p. 15, transl. Lasner). Region-marketing is a more precisely defined term than the more widely used phrase "regional marketing", which is often also used for marketing local commodities. Region-marketing is more narrowly concerned with the marketing of a region itself [22], through the establishment of a corporate identity [21].

Our study outlines the uncertainties of carp farmers today perceived by local stakeholders in the Aischgrund and Baryzc Valley. Our study further identifies the diverse measures of regionmarketing initiated by the stakeholders and try to classify them economically. Data about economics of carp aquaculture is poor in Europe. Aggregated statistics short come in terms of micro-economic information. That is why, our study applied an alternative means of data collection to analyse farm profitability: the typical farm approach according to the agri benchmark network [25]. Our study analyses the economics of typical carp farms and discuss how the region-marketing meets the economic needs of carp farms.

The following chapter describes the mixed method approach applied. Chapter three presents the challenges of carp farmers perceived by the stakeholders interviewed in the Aischgrund and Barycz Valley followed by an identification of measures of region-marketing in a first section. The second section of chapter three analyses the economic situation of carp farms with a special focus on the traditional carp grow-out business and discusses the impact of region-marketing. Chapter four concludes what the evaluated farm economics and region-marketing measures mean for the future development of carp farming.

\section{Materials and Methods}

\subsection{Expert interviews}

In order to explore challenges faced by carp farmers and the measures of region-marketing a purposive sample of 17 experts were interviewed (cf. appendix A). The general aim of qualitative approaches is to explore the diversity of perspectives inside a specific community regarding a particular situation and to explain their sense, rather than measuring variables $[26,27,28]$. From a sociological point of view, experts are carriers of specific technical, process or explanatory knowledge [29]. This knowledge helps in understanding the complexity of interactions in the research field. A defined expert does not represent a single protagonist, but offers an organization, company, institutional or professional perspective. The experts chosen had different professions; undertook diverse roles within the studied communities and in consequence had specific perspectives towards the region, its marketing and the situation for carp farming. Interviews were conducted in person, one-to-one or as part of focus groups. The experts came from cultural, touristic, nature conservation or carp farming institutions. The qualitative interviews were structured by a guideline. The questions of the guideline addressed the type and activities of the represented institution, the touristic attractiveness of the region and the role of carp farming in the region (cf. appendix B). 
Some of the chosen experts were local opinion leaders - individuals whose perspectives and actions have a notable influence on decision-making by other community members. Opinion leaders play an important role in establishing new ideas [30]. They often hold key positions in their community, as directors, mayors, principals, industrial patrons etc. The face-to-face interviews lasted between 30 and 60 minutes. Although the interviews followed a pre-defined structure, interviewees had still a great deal of leeway to reply, as it is usual in qualitative interview design [27]. The interviews took place at interviewee workplaces (office, restaurant or carp farm).

\subsection{Typical farm approach}

The typical farm approach is, in essence, a modal one [31,32,33,34], which constructs empirically grounded "virtual" farm datasets. The method was applied to aquaculture for the first time in 2014 [25]. All economic farm data resulted from close interactions between practitioners and researchers. The resulting datasets contain a maximum of 243 economic variables. The quantity of variables permits a high-resolution micro economic analysis, and their coherence serves as an indicator of data quality (validation). Figure 3 is a schematic representation of the typical farm approach, according to Lasner et al. [25].

Figure 3: Scheme of the typical farm approach [25]

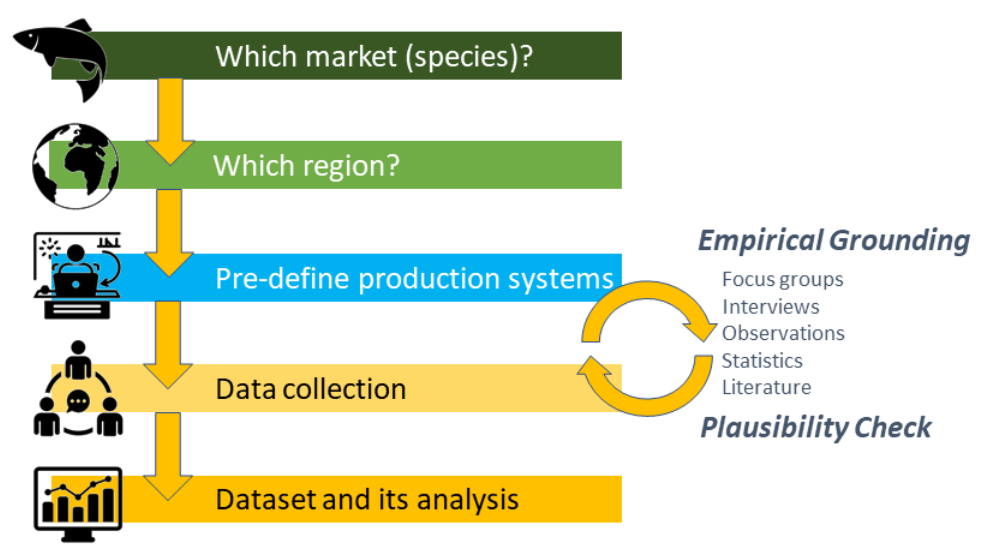

The typical farm approach is about farms' datasets, which are stable in characteristics, earns adequate profit, not the best, not the last, not top equipped, but well, which represent a group of farms using a common production method [31,32]. The farm models base on real costs, investments and prices. The farm models combine resources, labour and capital as it is established in the management today [31,34]. The approach concept relies on diverse sources for pre-defining the selected case (statistics, reports etc.), but the proof of the cases' characteristics is empirical. Core element of empirical data collection is the focus group with fish farmers. The majority of interviewed farmers and their representatives (cf. annex A) also participated in two focus groups which served to define the economics of typical and good practice carp farms in each region [36]. In doing so, the coherent picture of a farm model is built up by reaching a consensus among the focus group. Simultaneously, and in contrast to statistical averages, the defined variables control each other: e.g. the Feed Conversion Rate (FCR) should meet the volume of fish feed used and the feed costs should be in line with the feed volume and the feed price etc. Finally the modelled typical farms are doublechecked by fish farmers to real existing fish farms and by researchers to existing knowledge. Once a dataset of a farm is defined, different economic operations on farm and enterprise level are possible (e.g. profit and loss account, profitability, sensitivity analysis, economic and physical productivity).

Each modelled farm was issued a farm code, which references the ISO 639 country code, the FAO 3-Alpha Species Code (ASFIS) and the annual production of the main species of the farm in $\mathrm{mt}$ live weight $(\mathrm{LW})$. For example, the farm code «DE-FCP-5» refers to a German (DE) carp (FCP) farm 
model producing $5 \mathrm{mt}$ of carp in a typical year. The allocations used for the indicator report refer to returns of the carp grow-out system (at the farm gate) and the contribution of carp to profit and loss accounts, before tax. Focus group participants were able to provide confident estimates of costs based on their own business experience. Raw data were computed using the agri benchmark Fish ${ }^{4}$ simulation abFishCALC, which performs a range of economic efficiency analyses, with particular emphasis on cost calculations. Typical farm datasets consider economic indicators such as productivity ${ }^{5}$; variable and fixed costs ${ }^{6}$; wages ${ }^{7}$; depreciation (calculated linearly); opportunity costs (quantifying the value of self-owned resources ${ }^{8}$ ); and profitability ${ }^{9}$. The typical farm approach distinguishes three classes of costs, namely cash costs, depreciation and opportunity costs [25]. Short-term (up to 1 year), mediumterm (up to 5 years) and long-term (more than 5 years) profitability figures were obtained by subtracting the three cost classes step by step from returns. As the general reference year of the SUCCESS project ${ }^{10} 2015$ has been choosing as the starting point of the presented economic analysis. Unfortunately, this was not a typical year for the Aischgrund region, where carp production was negatively affected by a drought, resulting in productivity losses of up to -20 percent [35]. To maintain comparability, this extreme situation was not considered in our analysis. To analyse the profitability of the four selected carp farms, DE-FCP-5, DE-FCP-20, PL-FCP-90 and PL-FCP-190, our study first describes their cost structures, then looks at the various sale channels currently used by the farmers. In both regions the focus is on carp grow-out, which has formed the core of the carp farming business for decades. However, it is practice in Germany and Poland for larger farms rear their own carp fry and fingerlings for stocking. All costs and prices refer to $€$ per kg LW, unless otherwise stated.

Expert interviews and focus groups took place between June 27th - July $1^{\text {st }}, 2016$ in the Aischgrund in Germany and September 12 ${ }^{\text {th }}-16^{\text {th }}, 2016$ in the Barycz Valley. In 2018, the involved fish farmers and carp researchers were again interviewed. Via standardized questionnaire they updated prices and costs of the model farms for 2016 and 2017. In the model the production volume is assumed as stable from 2015 to 2017 . While changes in fish and feed prices, wages, interests, land prices were interviewed [36], national price indexes provide general information about the price developments for fixed costs, interest rates, currency rates and replacement values of equipment and facilities $[37,38]$.

\footnotetext{
${ }^{4}$ The German Thünen-Institute coordinates a worldwide non-profit network of agricultural economists and farmers, with experience in the typical farm approach since 2002: agri benchmark.

${ }^{5}$ Annual production, start weight fingerling, finishing weight, loss, Feed Conversion Rate (FCR), permanent labour, casual labour.

${ }^{6}$ Comprising costs of land or leaseholds, water charges, maintenance (buildings, ponds, machinery and equipment), administration (environmental controls, advisory services, certification, accounting), memberships, insurances, business operations and promotion; feed, fingerling stock, veterinary services (vaccination and drugs), smaller outlays on operational equipment, energy (electricity, diesel vehicles, oxygen) and other variable costs.

${ }^{7}$ Costs for paid labour and non-wage costs.

${ }^{8}$ Family labour (calculated as family working hours * wage for qualified local labour), land (own land area * regional land rents) and capital (non-land equity * long-term government bonds interest rate).

${ }^{9}$ Revenues from aquaculture, farming, additional income, interests on savings and subsidies.

10 "Strategic Use of Competitiveness towards Consolidating the Economic Sustainability of the european Seafood sector" (SUCCESS); grant no 635188 of the European Union's Horizon 2020 research and innovation program; this publication is part of the SUCCESS project; www.success-h2020.eu.
} 


\section{Results}

224 The first section presents a picture of the contemporary challenges for carp aquaculture as perceived by the interviewed stakeholders followed by a description of region-marketing measures established in the Aischgrund and Barycz Valley. The second section focuses on the economics of typical carp farms. Costs and profitability of selected carp grow-out operations in Germany and Poland are compared. Finally the effects of region-marketing's product labelling are analysed.

\subsection{Region-marketing}

The opinion leaders of the Aischgrund and Barycz Valley interviewed perceived the carp aquaculture as the corporative feature of their localities. «The people identify themselves with the carp. We are a carp region» [39]. The stakeholders emphasized the importance of carp farming for the identity of both regions [22]. «It's more than just producing fishes. Many people have a heart for the carp culture and the landscape» [9]. Regional initiatives have focused on the maintenance of ponds, on the unique landscape and culture of the region, on tourism development and on measures to enhance local fish production. These initiatives have been run by several local stakeholders and entrepreneurs, but carp farming has been the unifying leitmotiv for each one. The established region-marketing measures address the enhancement of profitability of both the carp (core product), and the services which are linked to the carp farming (product environment). "The carp is responsible for keeping these environmental good conditions. If local people cannot pay to protect the ponds and carp farming, tourist have to pay extra for it" [40]. These provisioning services incorporate the material and immaterial infrastructures involved in the production of carp, including those linked to farming (extensive production), marketing and externalities such as the heritage of fish farming and consumer culture, the pond landscape and its associated biodiversity. "It wouldn't be such landscapes, no animals to protect without carp ponds" [41].

In the Aischgrund, the association Karpfenland Aischgrund e.V. promotes the region and its links with carp farming [42], while Partnerstwo dla Doliny Baryczy (Barycz Valley Partnership) performs a similar role for the Barycz Valley [40]. Both associations are closely related to Fishery Local Action Groups (FLAG), which coordinate activities and applications for funding. Main sources of funding are EU programmes like the European Maritime and Fisheries Fund (EMFF) or Liaison Entre Actions de Développement de l'Économie Rurale (LEADER). Table 1 shows the diverse measures of region-marketing implemented since the 2000s.

Table 1: Measures of region-marketing and addressed issues in the Aischgrund and Barycz Valley

\begin{tabular}{|c|c|c|c|}
\hline Measure & Description & Addressed (main) issue & Region \\
\hline $\begin{array}{l}\text { Fishery Local } \\
\text { Action Group }\end{array}$ & $\begin{array}{l}\text { Collaboration of private and public partners to } \\
\text { establish a coherent programme of communication } \\
\text { and promotion }\end{array}$ & Organisation of action & kischnons \\
\hline New products & $\begin{array}{l}\text { The base innovation introduced is the bone cut } \\
\text { carp fillet. It is the starting material for various } \\
\text { further processed products like carp sushi, burger, } \\
\text { sausages, smoked carp fillets and more }\end{array}$ & Changed consumer preferences & 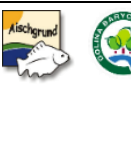 \\
\hline Labelling & $\begin{array}{l}\text { In 2006, the 'Milicki Carp from Lower Silesia' label } \\
\text { was included at the List of Traditional Products by } \\
\text { the Polish Ministry of Agriculture. Since 2012, } \\
\text { carp from the Aischgrund has been given the EU } \\
\text { Protected Geographic Indication label. }\end{array}$ & Price competition & (b) \\
\hline Carp museum & $\begin{array}{l}\text { Diffusion of knowledge about carp culture among } \\
\text { locals and visitors }\end{array}$ & $\begin{array}{l}\text { Regional identity; touristic } \\
\text { attractiveness }\end{array}$ & kisabrant. \\
\hline Tourist office & $\begin{array}{l}\text { Founding of a central contact point for tourists } \\
\text { (incl. central webpage); promotion at fairs, food } \\
\text { exhibitions and folk festivals }\end{array}$ & Touristic attractiveness & 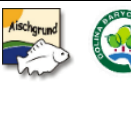 \\
\hline
\end{tabular}




\begin{tabular}{|c|c|c|c|}
\hline Carp events & $\begin{array}{l}\text { Season highlights like fish harvest parties or the } \\
\text { election of a "carp queen"; all-season activities } \\
\text { (angling, walking, bicycle routes, kayaking etc.); } \\
\text { establishing of off-season activities }\end{array}$ & $\begin{array}{l}\text { Touristic attractiveness; regional } \\
\text { identity; enlarge the carp season }\end{array}$ & 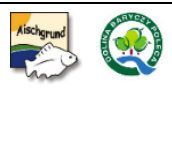 \\
\hline $\begin{array}{l}\text { Restaurant } \\
\text { network }\end{array}$ & $\begin{array}{l}\text { Network of restaurants known as 'fish kitchens', } \\
\text { exclusively serving labelled Aischgründer carp; } \\
\text { outlets in Bavarian metropoles }\end{array}$ & $\begin{array}{l}\text { Price competition; changed } \\
\text { consumer preferences; } \\
\text { imbalances at the supply chain }\end{array}$ & Riscignes \\
\hline $\begin{array}{l}\text { Carp pond } \\
\text { guides }\end{array}$ & $\begin{array}{l}\text { Guides presenting the pond landscape to visitors } \\
\text { from the perspective of a carp farmer }\end{array}$ & $\begin{array}{l}\text { Touristic attractiveness; } \\
\text { additional income }\end{array}$ & Ristons \\
\hline School teaching & $\begin{array}{l}\text { Provision of teaching materials and services for } \\
\text { local teachers }\end{array}$ & $\begin{array}{l}\text { Regional identity; changed } \\
\text { consumer preferences }\end{array}$ & \\
\hline
\end{tabular}

All measures address perceived challenges of the region and/or of carp farming in particular.

\subsection{Economics of carp farms}

Despite new business opportunities created by region-marketing, the traditional grown distribution to wholesalers is still the main sale channel for Aischgrund carp farmers. For carp farmers in Barycz Valley the sale to super and local markets is still most important. This concentrated composition of the value chain characterises the economics of carp farms in both regions.

\footnotetext{
${ }^{11}$ Carp for consumption needs three summers to reach grown-out size. The hatchery takes plays in the first year and the nursery in the second year.
} 


\subsubsection{Gross revenues}

Aischgrund carp farms are usually small-scale with less than 5 ha of culture area and very little in the way of machinery or other assets. On average, ponds have a surface area of 0.4 ha, with around 6 to 10 ponds per farm. Fewer than five farms in the region are larger than 50 ha. It is common for (agricultural) farmers in Franconia to earn an additional income from carp farming. Often they work as employees in other sectors or gain income from crop farming. The Aischgrund is located within the metropolitan region Nuremberg-Erlangen. A couple of international businesses have production sites here, providing alternative jobs and wealth for the region. A trend of increasing contractual conservation management agreements between the Bavarian State and carp farmers become is resulting in an important extra income source for the carp farmers [45], with those who commit themselves to extensive production methods and low stocking densities benefitting from public payments $(200 € / \mathrm{ha})$. As members of the agricultural sector, they also benefit from subsidised diesel prices $(0.91 € / 1)$. Figure 4 shows gross receipt sources of the two analysed farms DE-FCP-5 and DEFCP-20.

Figure 4: Gross revenues of selected carp farms in the Aischgrund 2017 (in €)

DE-FCP-5

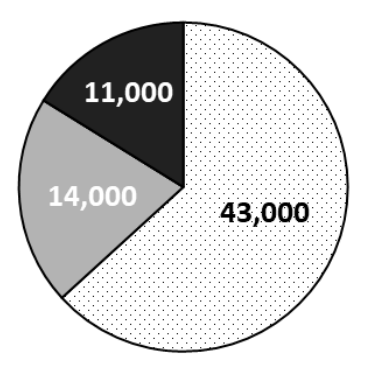

$\square$ External income

$\square$ Agricultural farm

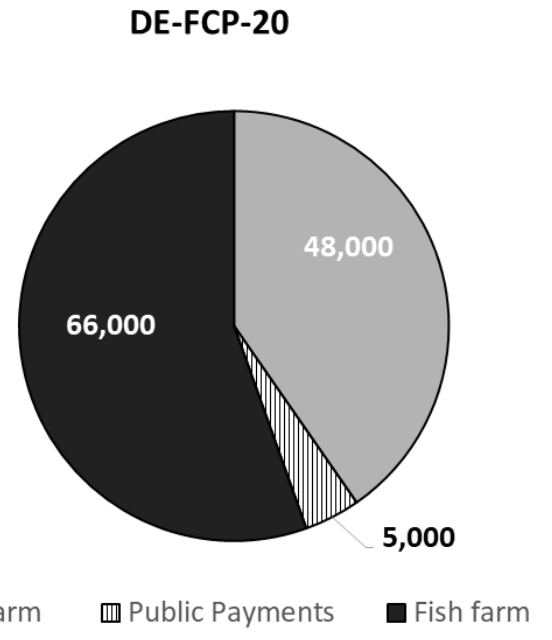

The typical farm DE-FCP-5 represents a type very common in the Bavarian Aischgrund in terms of structure and economic performance: small, family-owned, specialising in grow-out and an additional business for the owner. The farm DE-FCP-20 can be seen as an example of a good practice carp farm, one of relatively few larger scaled operations in the Aischgrund. DE-FCP-20 has an additional crop enterprise, which also supplies the carp farm with grain as fish feed.

Carp farmers from Barycz Valley often produce crops for carp farm owners and often part of the land area of aquaculture farms is used for carp feed production (grain). On many medium-sized farms, grain production delivers more than half of the required volume of feed (mixed grain) for fish. Two farms in the Barycz Valley were defined by focus group, farmer interviews and farm visits as typical for a given business scale: the medium-sized intensive cultivated PL-FCP-90 (70 ha fish ponds and 150 ha arable land) and the large-scale more extensive managed PL-FCP-190 (300 ha fish ponds). Figure 5 breaks down the normal income sources for each. 
Figure 5: Gross revenues of selected carp farms in Barycz Valley 2017 (in €)

PL-FCP-90

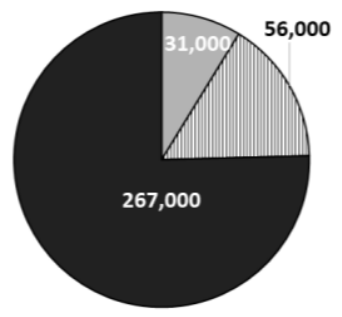

๑External income $\square$ Agricultural farm

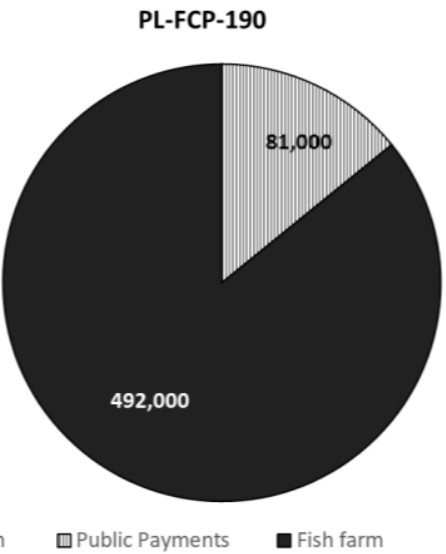

Besides income from fish and agricultural farming, carp farms in Lower Silesia are eligible for EU area payments for agricultural land. These direct, per-hectare payments are set at a minimal level because ponds are classified within the worst soil quality category. Nevertheless, income of this kind plays a larger role in supporting Barycz Valley carp farms than those in the Aischgrund. According to the Barycz Valley focus group, payments for agricultural land amounted to $236 € /$ ha in the studied period 2015-2017. In addition, almost all diesel expenditure was refunded, up to a limit of $19.27 € /$ ha. However, diesel is not considered a decisive expense for carp farms' cost structure in general.

\subsubsection{Cost structure}

Smaller farms purchase fingerlings for stocking their grow-out ponds, and the expense of doing so is the most important cost in carp farming (Table 2). In the Aischgrund, stocking costs are greatly increased as a result of predation by cormorants and other wild animals. Mortality one-summer-old carp fry, with a final weight of about $25 \mathrm{~g}$ each can reach 75 percent ( 50 percent in Barycz Valley). For two-summer-old carp fingerlings, with a final weight of $300 \mathrm{~g}$ each, the mortality is also high, at between 50 percent and 60 percent in the Aischgrund ( 20 percent in Barycz Valley). In consequence, the costs for stocking are significantly higher in the Aischgrund than in the Barycz Valley, where Stawy Milickie's large pond area deflect the attention of avian predators away from smaller enterprises and in consequence seems to reduce their fish loss in general. Furthermore, Polish farmers have invested in predator deterrent measures (e.g. designed fencing, reinforced moats and sound systems).

Table 2: Cash costs (€/kg LW) in selected carp grow-out systems 2017

\begin{tabular}{|c|c|c|c|c|}
\hline \multirow{2}{*}{ Costs $(€ / \mathrm{kg} L W)$} & \multicolumn{4}{|c|}{ Farm } \\
\cline { 2 - 5 } & DE-FCP-5 & DE-FCP-20 & PL-FCP-90 & PL-FCP-190 \\
\hline Stocking & 0.99 & 1.04 & 0.63 & 0.63 \\
\hline Feed & 0.24 & 0.45 & 0.58 & 0.63 \\
\hline Wages & - & - & 0.44 & 0.63 \\
\hline Oxygen & - & - & & 0.01 \\
\hline Power & - & - & 0.04 & 0.02 \\
\hline Interests & - & 0.08 & - & - \\
\hline Other variable costs & 0.19 & 0.09 & 0.15 & 0.11 \\
\hline Fixed costs & 0.23 & 0.22 & 0.47 & 0.34 \\
\hline TOTAL CASH COSTS & $\mathbf{1 . 6 6}$ & $\mathbf{1 . 9 2}$ & $\mathbf{2 . 3 7}$ & $\mathbf{2 . 0 8}$ \\
\hline
\end{tabular}


Table 3: Depreciation and opportunity costs $(€ / \mathrm{kg} L W)$ of selected carp grow-out systems in 2017

\begin{tabular}{|l|c|c|c|c|}
\hline \multirow{2}{*}{ COSTS $(€ /$ kg LW) } & \multicolumn{4}{|c|}{ Farm } \\
\cline { 2 - 5 } & DE-FCP-5 & DE-FCP-20 & PL-FCP-90 & PL-FCP-190 \\
\hline Depreciation & $\mathbf{1 . 1 7}$ & $\mathbf{0 . 4 7}$ & $\mathbf{0 . 4 9}$ & $\mathbf{0 . 6 5}$ \\
\hline Opportunity Costs & $\mathbf{1 . 1 3}$ & $\mathbf{0 . 6 0}$ & $\mathbf{0 . 3 5}$ & \multicolumn{1}{|c|}{$\mathbf{0 . 6 6}$} \\
\hline thereof unpaid labour & 0.90 & 0.41 & 0.26 & 0.18 \\
\hline Capital & 0.09 & 0.03 & 0.07 & 0.08 \\
\hline Land & 0.14 & 0.16 & 0.02 & 0.39 \\
\hline
\end{tabular}

The value of cash costs, depreciation and opportunity costs for different farms can be combined into statements about the short-, mid- and long-term profitability of carp grow-out systems.

\subsubsection{Profitability}

Small-scale carp farmers in the Aischgrund generally lack storage capacity and thus depend on wholesalers who can purchase all fish immediately after harvest. Such uncomplicated sales result in low prices for the farmer. In opposite, large-scale farmers are able to store the carp alive in special ponds after the harvest for weeks. In the Aischgrund, fewer than five carp farms operate on more than 50 ha, but these few are able to process their own fish, diversify their distribution and product range. For example, since the millennium, bone-cut carp fillets have become established as a product in the Aischgrund, alongside traditional carp-halves and are becoming popular as an ingredient for 
several carp dishes (e. g. carp burger, sausages, crisps). Nevertheless, wholesaling remains the standard sales route for carp farming. The carp season is from autumn (harvest) to spring (Easter). According to the focus group and expert interviews, the prices paid by wholesalers and processors was around $2.30 € / \mathrm{kg}$ LW between 2015 to 2017 in the Aischgrund. Typical small farms as DE-FCP-5 had to cope only $2.20 € / \mathrm{kg} \mathrm{LW}$ in 2017 due to price transmission from (Czech) imports and the fact, that Aischgrund smallholders are price takers in an unbalanced supply chain. The gross margin for Aischgrund farms, which sell carp to the wholesale, was between 17 and 25 percent, without considering linear depreciation and hypothetical opportunity costs. The gross margin of wholesalers supporting retail and gastronomy was 18 percent according to national data [46, 47, 48, 49]. With 55 percent Gastronomy in the Aischgrund had the highest gross margin in the value chain. Some restaurants sold the fried carp for $22 € / \mathrm{kg}$ and had assumed costs of almost $10 € / \mathrm{kg} \mathrm{LW}$. In the Barycz Valley, the carp season is very short, mainly for historical and cultural reasons. 90 percent of production is sold around Christmas time. There is no fish processing industry in Lower Silesia, and the main product remains fresh, unprocessed carp, which is mainly distributed via super and local markets. The gross margins for retailers were 36 percent respectively for retailers and local markets [50]. For the Barycz Valley farms the gross margin was around 30 percent in an average for all distribution channels, without considering linear depreciation and hypothetical opportunity costs.

Taking into account the volumes distributed via each of the different sale channels, weighted means for returns per $\mathrm{kg}$ LW were calculated for each farm. DE-FCP-5 realizes $2.20 € / \mathrm{kg} \mathrm{LW}$, while for DE-FCP-20, wholesales at $2.30 € / \mathrm{kg} \mathrm{LW}$ are boosted by sales to the gastronomy at $4.10 € / \mathrm{kg} \mathrm{LW}$ to realize an average of $2.67 € / \mathrm{kg} L W$. PL-FCP-90 earns $3.39 € / \mathrm{kg} L W$ and PL-FCP-190 receives $2.88 € / \mathrm{kg}$ LW on average for their carp. Polish carp prices were higher in general. The figures take into account payments for agricultural land and refunds on diesel. DE-FCP-5 is the only farm, which does not benefit significantly from public payments. Figure 6 compares the profitability of the studied German and Polish carp grow-out systems from 2015 to 2017.

420

421

Figure 6: Cash costs, non-cash costs and market returns ( $€ / \mathrm{kg} \mathrm{LW})$ of selected carp grow-outs 2015-2017

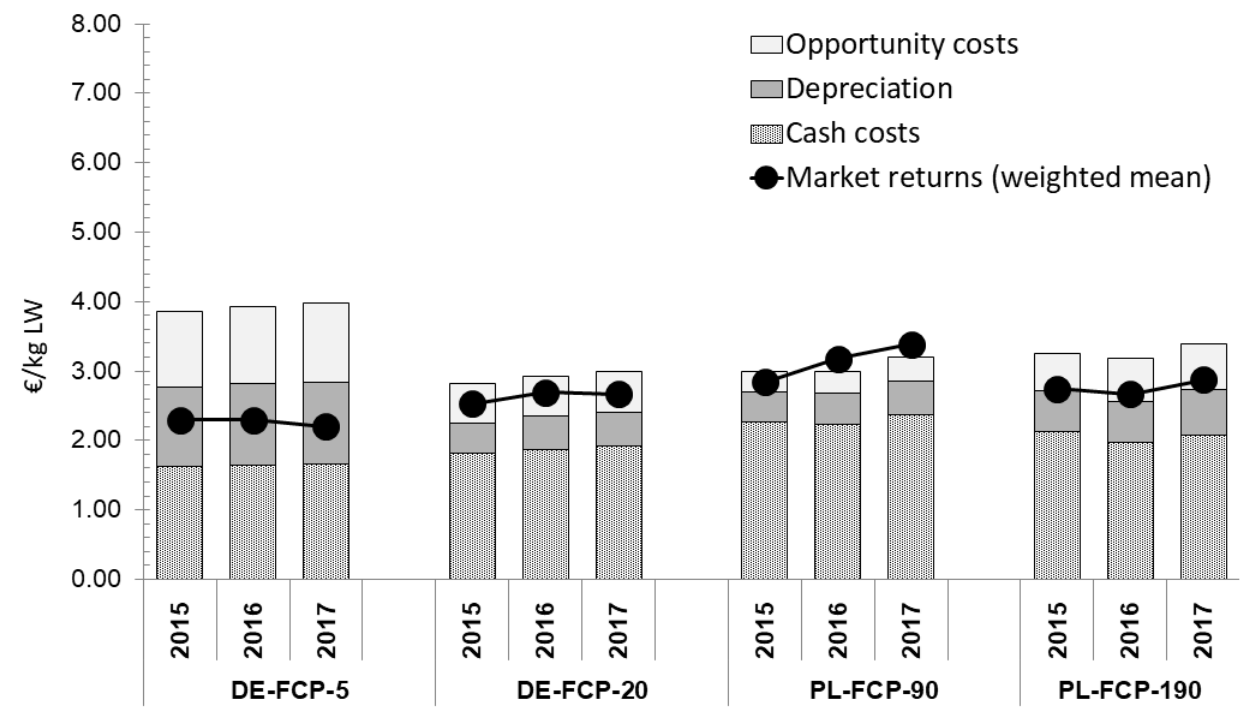

The greater the disparity between market return and total costs, the more profitable a farm is. In all cases, our study farms were able to cover their cash costs, with the larger Polish farms PL-FCP-90 and PL-FCP-190 most profitable from a short-term. In the medium-term however, the Aischgrund typical small farm DE-FCP-5 is not profitable enough to cover its fictive depreciations, having no capital for investments beyond its daily business costs. Further, the scale-effect leads to disadvantages in depreciation (must-have of a base farm equipment independent from size) and price taking for DE-FCP-5. Without a storage possibility, DE-FCP-5 did not participate in the positive carp price 
development in 2016 and 2017. Anyway, the results show that small farms like DE-FCP-5 relying solely on carp grow-out and sales of fresh fish will not be profitable in the midterm. Even the German good practice farm DE-FCP-20 operates at the limit of economic viability in long-terms. If public payments of $0.10 € / \mathrm{kg}$ LW would not be considered, the situation for DE-FCP-20 would be harsh. A similar picture emerged with the typical Polish farm PL-FCP-190. Further PL-FCP-190 does not maximize its respective production potential managing the farm only semi-intensive, which leads to a non-optimal relation of declining costs per kg LW. Further, PL-FCP-190 focuses on wholesale distribution, where profit margin had been reduce caused by a weak Polish Zloty in 2016 in particular (currency effect). Only the diversified and intensive managed Polish farm PL-FCP-90 can be seen as significant profitable benefiting from higher carp prices for varied sale channels, but wholesaling and declining costs per kg LW carp optimizing its stocking management. Against that background PLFCP-90 can be seen as a good practice farm.

Given the overall harsh economics of carp grow-out, farmers have three main opportunities to adapt and enhance their situation, namely upscaling operations; introducing vertical integration and diversification. For small farms, upscaling does not necessarily mean acquiring additional new ponds in order to increase production, indeed opportunities to purchase ponds in both regions are virtually non-existent and authorization to construct new ponds is unlikely to be granted. This leaves the formation of production cooperatives as the only realistic means of upscaling for small operators, but this seldom happens, as such businesses lack the necessary resources of capital, time as well as relevant qualifications. Among those who farm carp as an additional activity, there is often little interest in changing the situation at all. Some of the factors influencing costs are beyond the control of small farmers. Increased predator management would reduce the mortality of carp fry and fingerlings, reducing one of the most important cash costs. On the other hand, higher payments for ecosystem services or monetary compensation for fish losses to bird predation could balance the financial equation. This is a thorny management issue with which the interests of carp farmers and nature protection have conflicted for decades, but recent developments in contractual nature conservation in Bavaria hint at a promising new spirit of cooperation between carp farmers and conservationists [45].

In contrast to the small-scale farms, large-scale operations in both study regions have already begun to adapt through vertical integration and diversification, for example by developing hatcheries, nurseries, storage and processing facilities, farm shops, fish restaurants and angling ponds. This potential for strengthening direct marketing and increasing visitor frequency are key in attracting potential customers, and it is in these crucial areas that the concept of region-marketing offers most promise, in both the Aischgrund and the Barycz Valley.

\subsubsection{Effects of PGI labelling in the Aischgrund}

While the majority of region-marketing initiatives are hardly to measure in case of their direct impact towards carp farms economics, the 2012 introduced PGI label lead directly to higher prices in the region, wholesaler have been willing to pay for certified 'Aischgründer Carp'. In 2006, the 'Milicki Carp from Lower Silesia' label was developed and included at the List of Traditional Products by the Polish Ministry of Agriculture and Rural Development. Notwithstanding and in contrast to the PGI labelled 'Aischgründer Carp' it has not an effect towards the price negotiations. According to interviewed Polish stakeholders, this non-price effect is caused by the fact, that the produced carp is distributed to the national market first of all and not regionally. Thus, it will not be considered in the following. 


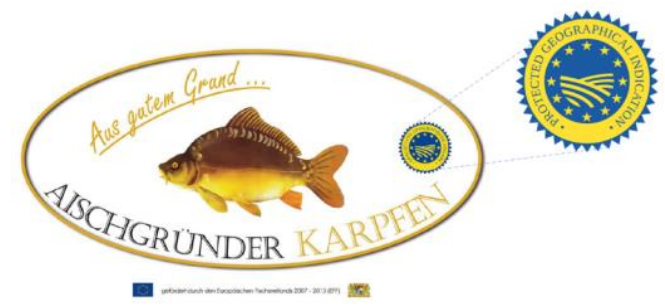

In 2018, 140 carp farmers operating 550 ponds (500 ha) were given PGI certification [36]. That corresponds to a share of about 15 percent of total carp farmers and 25 percent of total production in the Aischgrund. That is a slight increase of labelled producers since 2015. Furthermore, 40 restaurants were members of the PGI carp distributing network. The wholesaler price for labeled carp in the Aischgrund, has remained stable of $3.00 € / \mathrm{kg}$ LW for carp farmers from 2015 to 2017. These developments infer that there is a certain demand for labelled local carp. There are no additional costs for certifications like licenses for the farmers. Moreover, the producer organizations cover the control cost. The costs of certification are already included in the member fees of the producer organization, whether or not the farmer label his/her carp. Nonetheless, fish farmers have to meet the following pre-conditions for the certification: a lipid content $<10$ percent in the fish meat and the high-backed phenotype, which characterizes the regional carp race; a max. stocking density of 800 two-summerold carp per ha; a max. harvest of 1,300 kg three-summer-old carp per ha; grain, legumes or compound feed according to Bavarian regulations for the cultural landscape program as additional feed; good water quality. In fact, these pre-conditions do not effect productivity and reflect the current good production practices in the region. Figure 8 shows, how profitability growths in the case of PGI certified carp farms in the Aischgrund.

Figure 8: Cash costs, non-cash costs and market returns ( $€ / \mathrm{kg} L W)$ of PGI certified carp grow-outs 2015-2017

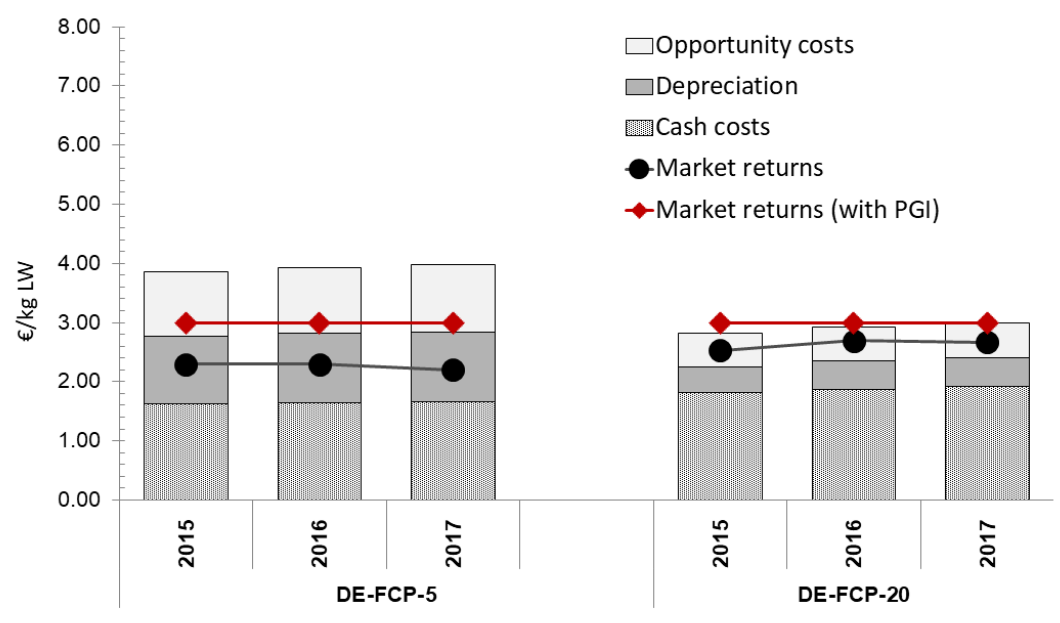

In both cases, higher market returns caused by higher prices gained for a PGI labelled carp lead to significant higher profitability. In particular, for the Aischgründer good practice carp grow-out DE-FCP-20, the higher returns ensures its long-term profitability, while the typical smallholder carp grow-out DE-FCP-5 still struggles to cover its opportunity costs. Notwithstanding, the results show, that creating a local certified brand can be seen as a successful opportunity to enhance the overall profitability. Moreover, it enables small-scaled carp farms to directly participant in the benefits of region-marketing. 


\section{Discussion and Conclusions}

514 "Nature like this, like the tiny little ponds and the history behind it, this is something you do not find quite often in Europe anymore" [42].

The results of this field study suggest that stakeholders in both regions have a firm grasp of the challenges facing carp farming and a good understanding of how to meet them. Although the Aischgrund and the Barycz Valley differ in the structure and history of their carp farming, they share a focus on traditional grow-out farming and the problem that fresh carp is hardly a profitable product on its own. Carp farmers in both regions struggle with increased costs and low wholesale margins. Changing consumer preferences, price competition, imbalances at the value chain, low levels of innovation, lack of farm successors, high fish losses to predation, diseases, shortage of water and rural de-population are forcing farmers to seek new business strategies. But the options are limited to specialization, vertical integration, diversification or upscaling. Large farms in Poland have specialized their production, allowing them to benefit from scale effects. They mainly address the Polish national market and can reduce costs by intensifying production like PL-FCP-190. For medium farms in both regions (DE-FCP-20 and PL-FCP-90), diversifying and vertical integration by closing carp production cycles is the best option, leading to lower fingerling costs, making operations less vulnerable to diseases and offering the opportunity to sell fish for re-stocking as well as consumption via different sale channels. The carp restaurant network in the Aischgrund enables alternative sale channels and secures the demand. Anyway, opportunities to lower fixed costs and depreciation by upscaling are limited by available pond area. In both regions there is an urgent need to increase the price of carp significantly. According to currently given cost structures in 2017, mean returns of between $3.00 € / \mathrm{kg}$ LW (DE-FCP-20) and 3.97 €/kg LW (DE-FCP-5) are necessary to ensure long term profits in the Aischgrund while in the Barycz Valley, farmers should be looking for mean returns of $3.20 € / \mathrm{kg}$ LW (PL-FCP-90) to $3.39 € / \mathrm{kg}$ LW (PL-FCP-190). In case of the Aischgrund, the new market segment for PGI labeled carps meets this necessary partly. However, well-developed directmarketing is a promising option for medium-scaled farms in both regions. Here, the offer of processed carp products like the bone cut fillet is an already established added value.

The interviews and focus groups suggest that significant efforts have been made to prepare carp farming (and the rural area) for the future, though there is room for greater cooperation between stakeholders such as Stawy Milickie and Partnerstwo dla Doliny Baryczy, which currently act more as competitors than partners. While region-marketing is recognized as a promising concept, a crucial question remains as to how the various activities might be converted into extra income with which carp farmers can maintain the landscape and cultural aspects associated with this fragile economic sector.

Improved recognition of products at national market level through region-marketing might bring indirect benefits to large farms like PL-FCP-190. Medium-scale farms like DE-FCP-20 and PLFCP-90 could profit from higher customer frequency, if they are able to further develop direct marketing. The challenge is greater for small farms such as DE-FCP-5 because of the costs involved in adaptation. Such operators are caught in a vicious circle: with carp farming on a small scale being un-profitable in long-terms, it tends to be a sideline business; for which the levels of (re-)investments are very low. If such businesses are not able to work much more closely together to achieve real production, storage and/or marketing cooperatives that shorten supply chains and strengthen their market position, small scale carp farming will be relegated to a hobby activity. But, in the Aischgrund in particular, the loss of these small carp farms and the landscape, heritage and tourism value they impart would be a serious economic, ecological and cultural crisis. A structural change towards fewer larger and more competitive farms would be a likely consequence, as already seen in other agribusiness sectors. If there is no re-structuring, and no development of strong cooperatives, the area risks losing the pond landscapes that lie at the core of its region-marketing strategy within a generation. Without the annual production cycle of stocking, dam maintenance, harvesting, liming, draining and re-filling, carp ponds overgrow and turn into fallow land within a few years. Is the cost of maintaining thousands of hectares of carp ponds for their environmental and heritage value alone something the public purse can afford? What would that cost be? 
A central lesson learned studying the carp case is that remunerating producers for the multifunctional services they provide would certainly increase their profitability while at the same time help in achieving other environmental and social goals. Such measures would well suited to the $2^{\text {nd }}$ pillar of the Common Agricultural Policy (CAP), which rewards services and revitalization of villages in rural areas, includes payments linked to Natura 2000 and the Water Framework Directive and payments for areas facing natural or other specific constraints. More, it is the view of the industry that reformed public funding programs should include compensation payments for fish losses through predation, along the lines of those currently made under the German wolf resettlement programs. Such payments are already applicated in some German federal states [51], but a national strategy is missing. A further private transfer payment could incorporate a visitors carp tax, whereby a small extra payment for each tourist overnight stay goes towards maintaining the iconic landscape and heritage visitors come to enjoy. The latter could be an extension of the PGI regional carp label which is already proving effective region-marketing tool in local restaurants in the Aischgrund. Private payments of this sort could be collected in a fund, which pays small scale farmers a subsidy per pond-hectare in recognition of their contribution towards the attractiveness of the region. Such a scheme would directly link profits in the tourism sector with those of carp farmers on which the recreational development of the region so heavily depends. A threshold should be established, for such payments because larger farms are better able to profit from touristic development through diversification and thus less in need of support.

None of the presented adaptation strategies will solve the problems facing carp farmers, in either of the study regions. Ultimately securing a future for both of these 'carp lands' is likely to require a mix of region-marketing, vertical integration, upscaling and diversification, the rather rapid establishment of farm cooperatives, enhanced predator management, payments for ecosystems (and cultural) services provided and wholehearted and careful collaboration between stakeholders.

Funding: Our study is part of the research project (2015-2018) "Strategic Use of Competitiveness towards Consolidating the Economic Sustainability of the european Seafood sector" (SUCCESS) and has received funding from the European Union's Horizon 2020 research and innovation program under the grant no 635188. Further single economic elements (farm economics DE-FCP-5 and -20) are part of a pilot study (2015-2016), which has received funding from the EU Data Collection Framework (DCF).

Acknowledgments: Our gratitude and appreciation are conveyed to all stakeholders and carp famers who enabled our research in the first place, namely listed in Table 1. Further, we'd like to thank Dr Magdalena Raftowicz-Filipkiewicz from National Marine Fisheries Research Institute (NMFRI) in Poland for her support during our fieldwork in Barycz Valley. We like to thank Dr Cornelia Kreiß from Thünen-Institute, Bremerhaven for her support in the data analysis and Amy-Jane Beer for the post-editing of our paper. 
1. Cyprinus carpio (Linnaeus, 1758). Cultured Aquatic Species Information Programme of the Food and Available online: http://www.fao.org/fishery/culturedspecies/Cyprinus_carpio/en\#tcNA003C (accessed on August 15, 2018).

2. Currie, C. The early history of carp and its economic significance in England. Agric Hist Rev 1991, 39 (2), 97-107.

3. Mück, W. Überlegungen zum Beginn der Teichwirtschaft im Aischgrund. In Geschichts- und Heimatverein Neustadt an der Aisch (ed.), Aischgründer Karpfenmuseum im Kulturareal Altes Schloss; Druckerei Münch: Neustadt an der Aisch, Germany, 2013. (transl. Thoughts about the beginning of carp farming in the Aischgrund. In History and Homeland Association Neustadt a. d. Aisch (ed.).

4. Füllner, G.; Pfeifer, M.; Langner, N. Karpfenteichwirtschaft. Bewirtschaftung von Karpfenteichen. Gute fachliche Praxis. Sächsische Landesanstalt für Landwirtschaft: Dresden, Germany, 2007. (transl. Carp aquaculture. Farming carp ponds. Best practices. Saxony State Agency for Agriculture).

5. Geldhauser, F.; Gerstner, P. Der Teichwirt; Ulmer: Stuttgart, Germany, 2003. (transl. The fish farmer).

6. Blanchard, J. L.; Watson, R. A.; Fulton, E. A.; Cottrell, R. S.; Nash, K. L.; Bryndum-Buchholz, A.; Büchner, M.; Carozza, D. A.; Cheung, W. W. L.; Elliott, J.; Davidson, L. N. K.; Dulvy, N. K.; Dunne, J. P.; Eddy, T. D.; Galbraith, E.; Lotze, H. K.; Maury, O.; Müller, C.; Tittensor, D. P.; Jennings, S. Linked sustainability challenges and trade-offs among fisheries, aquaculture and agriculture. Nat, Ecol \& Evol 2017, 1, 1240-1249. Available online: https://www.nature.com/articles/s41559-017-0258-8 (accessed on February 1, 2019).

7. Blayac, T.; Mathé, S.; Rey-Valette, H.; Fontaine, P. Perceptions of the services provided by pond fish farming in Lorraine (France), Ecol Econ 2014, 108, 115-123. Available online:

https://www.sciencedirect.com/science/article/pii/S0921800914003176 (accessed on 1 February 2019).

8. Hutchinson, L. Ecological aquaculture. A sustainable solution. Permanent Publications Hyden House: East Meon, Hampshire, UK, 2006.

9. Oberle, M. (Head of Carp Farming Department, Bavarian Institute of Fisheries, Bavarian State Agency for Agriculture, Höchstadt, Germany) Interview, June 30, 2016.

10. FAO. Statistical Query Results. Aquaculture: Quantity (t) 2008-2017. World. Inland waters. Freshwater. Common carp. Cyprinus carpio. Available online: http://www.fao.org/figis/servlet/SQServlet?file=/usr/local/tomcat/8.5.16/figis/webapps/figis/temp/hq p_9051681111959107287.xml\&outtype $=h t m l$ (accessed on September $6^{\text {th }}$, 2019)

11. EUMOFA. European Market Observatory for Fisheries and Aquaculture Products. Case study. Price structure in the supply chain for fresh carp in Central Europe. European Commission, DirectorateGeneral for Maritime Affairs and Fisheries; Publication Office of the European Union: Brussels, Belgium 2016.

12. FEAP. European Aquaculture Production Report 2008-2016. Prepared by the Federation of European Aquaculture Producers (FEAP): Liege, Belgium, 2017.

13. BLE (Bundesanstalt für Landwirtschaft und Ernährung). Answer of the Federal Office for Agriculture and Food on request of Dr Tobias Lasner, Thünen Institute of Fisheries Ecology. The German Seafood Market, annual data with focus on carp imports from 2000 to 2015. unpublished, 23 March 2017.

14. Destatis. Erzeugung in Aquakulturbetrieben 2016. Fachserie 3, Reihe 4.6. Land und Forstwirtschaft, Fischerei. Statistisches Bundesamt: Wiesbaden, Germany, 2017 (transl. Production of aquaculture farms 2016. National Agency for Statistics).

15. Klinkhardt, M. Wieviel Fisch erzeugen wir wirklich? FischMagazin 2014, 10, 3. (transl. How much fish do we really produce?).

16. Oberle, M. Rede: Vergleich der Ergebnisse der Aquakulturstatistik mit denen anderer Erhebungen für den Aischgrund. Speech: Starnberg, Germany, 7. September 2014. (transl. Comparing results of the official German aquaculture statistic with results of a regional data collection for Aischgrund. Upper Bavarian Fisheries Day at Starnberg). Available online: https://www.yumpu.com/de/document/read/24791182/dr-oberle-bayerische-landesanstalt-furlandwirtschaft-bayern (accessed on February 1, 2019). 
17. Rösch, R. (Senior researcher, Fisheries Research Station of Baden-Württemberg, Langenargen, Germany). Phone interview, October 8, 2015.

18. Ministerstwo Rolnictwa. Available online: https://www.gov.pl/web/rolnictwo (accessed on July 5, 2017).

19. Lirski, A.; Myszkowski, L. Polska akwakultura w 2013 roku na podstawie analizy kwestionariuszy RRW-22. Część II. Komunikaty Rybackie 2015, 1, 12-19. IRŚ, Olsztyn. (transl. Polish aquaculture in 2013 on the basis of RRW-22 questionnaires analyses. Part II).

20. Destatis. Erzeugung in Aquakulturbetrieben 2013. Fachserie 3, Reihe 4.6. Land und Forstwirtschaft, Fischerei. (transl. Production of aquaculture farms 2013. National Agency for Statistics).

21. Blotevogel, H. H. Zur Konjunktur der Regionsdiskurse. Info z. Raument 2000, 9/10, 491-506. (transl. Boom of region discourses. Information on spatial development).

22. Lindstaedt, T. Regionsmarketing und die Bedeutung regionsbezogener Identität. Technische Universität Darmstadt tuprints: Darmstadt, Germany, 2006. (transl. Region-marketing and significance of region-identity). Available online: http://tuprints.ulb.tu-darmstadt.de/744/ (accessed on February 1, 2019).

23. Kotler, P.; Haider, D.; Rein, I. Attracting investment, industry, and tourism to cities, states, and nations. Free Press: New York, USA, 1993.

24. Kotler, P.; Haider, D.; Rein, I. There's no place like our place! The marketing of cities, regions, and nations. The Futurist 1993, November/December, 15-21.

25. Lasner, T.; Brinker, A.; Nielsen, R.; Rad, F. Establishing a Benchmarking for Fish Farming. Profitability, Productivity and Energy Efficiency of German, Danish and Turkish Rainbow Trout Grow-out Systems. Aquac Resear 2017, 48, 3134-3148. Available online: https://onlinelibrary.wiley.com/doi/full/10.1111/are.13144 (accessed on February 1, 2019).

26. Lasner, T.; Hamm, U. Exploring Ecopreneurship in the Blue Growth: A Grounded Theory Approach. Ann of Mar Sociol 2014, 23, 4-20. Available online: http://cejsh.icm.edu.pl/cejsh/element/bwmeta1.element.desklight-40e73e54-109b-4275-96ac1aedd22967d0 (accessed on February 1, 2019).

27. Bryman, A. Social research methods. University press: Oxford, UK, 2012.

28. Anderson, M. L. ; Taylor, H. F.. Sociology: The Essentials. Wadsworth, Belmont, CA, USA, 2006.

29. Bogner, A.; Littig, B.; Menz, W. Interviewing experts. Methodology and practice. Palgrave Macmillan: Basingstoke, UK, 2009.

30. Rogers, E. M. Diffusion of Innovations. Free Press, New York, USA, 2003.

31. Zimmer, Y; Deblitz, C. agri benchmark Cash Crop: a standard operating procedure (SOP) to define typical farms. Federal Agricultural Research Centre, Braunschweig, Germany, 2005. Available online: http://literatur.thuenen.de/digbib_extern/dk038513.pdf (accessed on February 1, 2019).

32. Feuz, D.; Skold, M. Typical Farm Theory in Agricultural Research. Econ Staff Paper Ser, 1990, 75, 1-20. Available online: http://openprairie.sdstate.edu/econ_staffpaper/75 (accessed on February 1, 2019).

33. Walther, S. Determinants of competitiveness of agriholdings and independent farms in Ukrainian arable production. Thün Reports, 15, Johann Heinrich von Thünen Institute: Braunschweig, Germany, 2014. Available online: https://literatur.thuenen.de/digbib_extern/dn053389.pdf (accessed on January 9, 2019).

34. Isermeyer, F. Methodologies and comparisons of production costs - a global overview. In Sustainability and production costs in the global farming sector: comparative analysis and methodologies; Langrell, S.; Ciaian, P.; Gomez y Paloma, S. Eds.; Joint Research Center (JRC), Scientific and Policy Reports, European Commission: Brussels, Belgium 2012. Available online: https://ec.europa.eu/jrc/en/publication/eur-scientific-and-technical-research-reports/sustainabilityand-production-costs-global-farming-sector-comparative-analysis-and (accessed on January 92019 ).

35. Speierl, T.; Abt, S.; Schwinger, V.; Kuhlen, K.; Thoma, P. Rückblick auf den Hitzesommer 2015 Auswirkungen auf die Teichwirtschaft in Oberfranken. Fischer \& Teichwirt 2017, 05/2017, 167-170. (transl. Review of the hot summer 2015 - impacts on the fish farming in Upper Franconia).

36. Oberle, M. Modell Karpfenbetrieb. Personal correspondence, December 14, 2018.

37. For German farms projection bases on: Destatis. Preise, Fachserie 17 Reihe 1, Preisindizes in der Land- und Forstwirtschaft. Statistisches Bundesamt: Wiesbaden, Germany November 2018 (transl. Prices, Volume 17/1, 7 Price indices in agriculture and forestry). For Polish farms projection bases on indices from the The Agricultural Property Agency (ANR), Central Statistical Office (Statistics Poland 
https://stat.gov.pl/en/) and Institute of Agricultural and Food Economics - National Research Institute (https://www.ierigz.waw.pl).

38. OANDA. Currency converter, exchange rates EUR=PLN December 31st, 2015, 2016, 2017. Available online: https://www.oanda.com/ (accessed on January 9, 2019).

39. Kabelitz, K. (Founder and Senior Partner of Homeland and Carp Museum, Neustadt an der Aisch, Germany). Interview, June 30, 2016.

40. Ozga, I. (Head of Fishery Local Action Group "Partnerstwo dla Doliny Baryczy", Milicz, Poland) Interview, September 15, 2016.

41. Śnigucki, P. (CEO of Lower Silesia Landscape Parks Complex, Biodiversity Center, Milicz, Poland). Interview, September 14, 2016.

42. Schuster, S. (Manager of the Tourist and Marketing Agency “Karpfenland Travel”, Höchstadt, Germany) Interview, June 30, 2016.

43. Bätzing, W. Nutzungskonflikte zwischen Teichwirtschaft, Naturschutz und Freizeitinteressen im Aischgrund. Probleme und Potenziale bei der Aufwertung des "Aischgründer Karpfens" zum Qualitätsregionalprodukt. Mitt d. Fränk Geo Gesell 2013, 59, 81-100. (transl. Conflicts between aquaculture, conservation and leisure interests in the Aischgrund. Problems and potentials by upgrading the "Aischgründer Carp" to a regional quality product. Journal of the Franconian Geography Society). Available online: http://fgg-erlangen.de/fgg/ojs/index.php/mfgg/article/view/265 (accessed on February 1, 2019).

44. Füllner, B.; Wedekind, H.; Oberle, M.; Bräuer, G.; Feneis, B. Untersuchungen zur Bewirtschaftung in der Karpfenteichwirtschaft vor dem Hintergrund der KHV-1. Schlussfolgerungen aus dem Mehrländerprojekt - Teil 1/3. In: Fischer \& Teichwirt 2016, 6, 207-209. (transl. Study of carp farming against the background of KHV-1. Conclusions from the intra-federal state project - part 1/3).

45. Güthler, W. Förderung einer naturverträglichen Teichbewirtschaftung durch das Bayerische Vertragsnaturschutzprogramm. Bayerisches Staatsministerium für Umwelt und Verbraucherschutz, Triesdorfer Fischereitag, Triesdorf, Germany, January 13, 2018. (transl. Supporting a nature-friendly aquaculture through the Bavarian contractual nature conservation. Baverian Ministry for Environment and Consumer Protection).

46. Destatis. Zahlen \& Fakten. Wirtschaftsbereiche. Land- \& Forstwirtschaft, Fischerei. Fischerei. Preise für ausgewählte Fischarten nach Vermarktungswegen 2015 [table]. (transl. Facts \& figures. Economic sectors. Agriculture and forestry, fisheries. Fisheries. Prices per sale channel for selected species 2015). Available online: https://www.destatis.de/DE/ZahlenFakten/Wirtschaftsbereiche/LandForstwirtschaftFischerei/Fischer ei/Tabellen/AquaPreise.html (accessed on October 25, 2017).

47. Oberle, M. Studies and activities aimed at improving the marketing of common carp in Bavaria. 3rd International Carp Conference, Vodnany, Czech Republic, September 3-4, 2015.

48. Brämick U. Jahresberichte zur Deutschen Binnenfischerei und Binnenaquakultur, 2013-2015. Institut für Binnenfischerei e. V., Potsdam-Sacrow (transl. Annual reports of fresh water fisheries and aquaculture).

49. Bundesanstalt für Landwirtschaft und Ernährung. Der Markt für Fischereierzeugnisse in der Bundesrepublik Deutschland, 2003-2016 (transl. Federal Office for Agriculture and Food. The German Seafood Market, annual reports). Available online: http://www.ble.de/DE/02_Kontrolle/02_Fischerei/01_Fischwirtschaft/Fischwirtschaft_node.html (accessed March 23, 2017).

50. Lirski, A.; Hryszko, K. Krajowa produkcja ryb i owoców morza. Rybactwo śródlądowe. Rynek Ryb. Stan i perspektywy, November 2015, 23. IERiGŻ, Warszawa, Poland. (transl. Polish production of fish and seafood. Inland fisheries. Fish market. Status quo and perspectives).

51. Sächsisches Staatsministerium für Umwelt und Landwirtschaft. Sachsen. Landwirtschaft. Berufsfischerei und Förderung. Härteausgleichsverordnung. (transl. Saxony Ministry for Environment and Agriculture. Commercial Fisheries and Funding. Compensation Payments). Available online: https://www.landwirtschaft.sachsen.de/berufsfischerei-und-foerderung-13804.html\#a-13811 (accessed September 20, 2019). 


\begin{tabular}{|c|c|c|c|c|}
\hline Region & Name & Profession & Position & Organisation \\
\hline \multirow{10}{*}{$\begin{array}{l}\text { AISCHGRUND } \\
\text { (DE) }\end{array}$} & Hans Frischmann & Carp farmer & Head of company & Teichwirtschaft Frischmann \\
\hline & Bernhard Feneis & Fish veterian & $\begin{array}{l}\text { Vice president } \\
\text { (FEAP), president } \\
\text { (VDBA) }\end{array}$ & $\begin{array}{l}\text { Federation of European Aquaculture } \\
\text { Producers (FEAP) and German } \\
\text { Aquaculture Association (VDBA) }\end{array}$ \\
\hline & Walter Jakob & Carp farmer & $\begin{array}{c}\text { Head of } \\
\text { association }\end{array}$ & $\begin{array}{l}\text { Teichgenossenschaft Aischgrund, } \\
\text { Höchstadt an der Aisch }\end{array}$ \\
\hline & Carola Kabelitz & Volunteer & $\begin{array}{c}\text { Founder and } \\
\text { senior partner }\end{array}$ & $\begin{array}{l}\text { Homeland and Carp Museum, } \\
\text { Neustadt an der Aisch }\end{array}$ \\
\hline & Christoph Oberle & $\begin{array}{c}\text { Carp farmer } \\
\text { and restaurant } \\
\text { owner } \\
\end{array}$ & Senior partner & $\begin{array}{l}\text { Carp Farm and Restaurant «Die } \\
\text { Fischerei », Erlangen-Kosbach }\end{array}$ \\
\hline & Dr Martin Oberle & Scientist & $\begin{array}{c}\text { Head of } \\
\text { department }\end{array}$ & $\begin{array}{c}\text { Bavarian State Research Center for } \\
\text { Agriculture, Institute for Fisheries, } \\
\text { Department for Carp Farming, } \\
\text { Höchstadt an der Aisch }\end{array}$ \\
\hline & Gerhard Schmidt & $\begin{array}{l}\text { Carp and crop } \\
\text { farmer }\end{array}$ & Head of company & $\begin{array}{l}\text { Teich- und Landwirtschaft Schmidt, } \\
\text { Höchstadt an der Aisch }\end{array}$ \\
\hline & Sandra Schuster & $\begin{array}{l}\text { Tourism } \\
\text { manager }\end{array}$ & $\begin{array}{l}\text { Manager of } \\
\text { agency }\end{array}$ & $\begin{array}{c}\text { Tourist and marketing agency } \\
\text { "Karpfenland Travel", Höchstadt an } \\
\text { der Aisch }\end{array}$ \\
\hline & Wolfgang Städtler & Carp farmer & Employee & $\begin{array}{c}\text { Bavarian State Research Center for } \\
\text { Agriculture, Institute for Fisheries, } \\
\text { Department for Carp Farming, } \\
\text { Höchstadt an der Aisch }\end{array}$ \\
\hline & Silvia Pertschi & $\begin{array}{l}\text { Museum } \\
\text { manager }\end{array}$ & Employee & $\begin{array}{l}\text { Homeland and Carp Museum, } \\
\text { Neustadt an der Aisch }\end{array}$ \\
\hline \multirow{7}{*}{$\begin{array}{l}\text { BARYCZ } \\
\text { VALLEY } \\
\text { (PL) }\end{array}$} & Inga Ozga & $\begin{array}{l}\text { Tourism } \\
\text { manager }\end{array}$ & Head of group & $\begin{array}{c}\text { Fishery Local Action Group } \\
\text { "Partnerstwo dla Doliny Baryczy", } \\
\text { Milicz }\end{array}$ \\
\hline & Lidia Raftowicz & $\begin{array}{c}\text { Restaurant } \\
\text { manager }\end{array}$ & Head of restaurant & $\begin{array}{c}\text { Carp farm and restaurant Raftowitz, } \\
\text { Ruda Żmigrodzka (Zmigród) }\end{array}$ \\
\hline & Karol Girus & Carp farmer & Head of company & $\begin{array}{l}\text { Carp farm Girus, Możdżanów } \\
\text { (Sośnie) }\end{array}$ \\
\hline & $\begin{array}{c}\text { Jan Krzysztof } \\
\text { Raftowicz }\end{array}$ & Carp farmer & Head of company & $\begin{array}{c}\text { Carp farm and restaurant Raftowitz, } \\
\text { Ruda Żmigrodzka (Zmigród) }\end{array}$ \\
\hline & $\begin{array}{c}\text { Robert } \\
\text { Lewandowski }\end{array}$ & Manager & Major & Żmigród town \\
\hline & Piotr Śnigucki & Manager & $\begin{array}{l}\text { Director of park } \\
\text { complex }\end{array}$ & $\begin{array}{l}\text { Dolnośląskie Voivodship, Lower } \\
\text { Silesia Landscape Parks Complex }\end{array}$ \\
\hline & Waldemar Mierzwa & Carp farmer & Head of company & $\begin{array}{c}\text { Carp farm Mierzwa, Krośnice } \\
\text { (Krośnce) }\end{array}$ \\
\hline
\end{tabular}


1. General introduction of the SUCCESS project and the case study on carp aquaculture

2. Specific questions per sector

A. Cultural and touristic sector

\begin{tabular}{|l|l|l|}
\hline The institution & - & First of all, could you please present the history of your institution? \\
\hline The region & - $\quad$ Could you please describe the activities done by the museum/tourist centre/park office? \\
\hline & - Which kind of clients do visit your region/your museum/your park? \\
& - Which is the main season for your visitors? \\
\hline - Why do people visit the region?
\end{tabular}

B. Carp farm sector

\begin{tabular}{|c|c|}
\hline $\begin{array}{l}\text { History of carp } \\
\text { farming }\end{array}$ & $\begin{array}{l}\text { - First of all, could you please sum up the history of carp farming in your region? } \\
\text { - } \quad \text { Please describe the link between carp farming and your region. } \\
\text { - Could you please describe the mentioned conflicts? }\end{array}$ \\
\hline $\begin{array}{l}\text { Carp ponds and } \\
\text { external effects }\end{array}$ & $\begin{array}{l}\text { - } \quad \text { Please, describe a typical production year in carp aquaculture. } \\
\text { - } \quad \text { What environmental effects result from carp farming? } \\
\text { - } \quad \text { How could those effects be measured? } \\
\text { - } \quad \text { How is the public perception of these effects? } \\
\text { - How could the public knowledge about carp aquaculture and its effects be improved? }\end{array}$ \\
\hline
\end{tabular}

4. What is the general public image of your region?

5. How does the future of carp farming looks like in your region? 
792 